\title{
Applying a Rational Approach to Judicial Independence and Accountability on Contemporary Issues
}

Thomas Tinkham

Follow this and additional works at: http://open.mitchellhamline.edu/wmlr

\section{Recommended Citation}

Tinkham, Thomas (2011) "Applying a Rational Approach to Judicial Independence and Accountability on Contemporary Issues," William Mitchell Law Review: Vol. 37: Iss. 3, Article 4.

Available at: http://open.mitchellhamline.edu/wmlr/vol37/iss3/4

This Article is brought to you for free and open access by the Law Reviews and Journals at Mitchell Hamline Open Access. It has been accepted for inclusion in William Mitchell Law Review by an authorized administrator of Mitchell Hamline Open Access. For more information, please contact sean.felhofer@mitchellhamline.edu.

(c) Mitchell Hamline School of Law

\section{$\mathrm{MH}$}

MITCHELL | HAMUINE OPEN ACCESS senod of the mitchellhamline.edu 


\title{
APPLYING A RATIONAL APPROACH TO JUDICIAL INDEPENDENCE AND ACCOUNTABILITY ON CONTEMPORARY ISSUES
}

\author{
Thomas Tinkham ${ }^{\dagger}$
}

I. INTRODUCTION 1633

II. THE NATURE AND History OF JUDICIAL INDEPENDENCE PERMITS SOME REASONABLE CONCLUSIONS ON COMPETING GOALS. 1637

III. AN APPLICATION OF GENERALLY ACCEPTED PROPOSITIONS TO SEVERAL CONTEMPORARY ISSUES ALLOWS REASONABLE CONCLUSIONS

IV. THE PRACTICAL LIMITS ON THE CONCEPTS OF JUDICIAL INDEPENDENCE AND ACCOUNTABILITY HAVE A BEARING ON OTHER CONTEMPORARY ISSUES.

V. DisSECTING THE DEBATE OVER ELECTIONS, APPOINTMENTS, AND REMOVAL OF JUDGES IN THE CONTEXT OF JUDICIAL INDEPENDENCE DEMONSTRATES THAT MODEST ENHANCEMENTS CAN REMEDY MORE COMPLAINTS ABOUT ELECTIONS 1655

VI. CONCLUSIONS 1663

\section{INTRODUCTION}

The function of the judicial branch is ever-increasing in many countries and most particularly the United States. ${ }^{1}$ The central role of courts in the United States demands a regular review of the theories that underlie their operation to ensure that the reality approximates the theory. With respect to its law-making function,

$\dagger$ Thomas Tinkham is a Visiting Professor of Law at William Mitchell College of Law and of Counsel with Dorsey \& Whitney, LLP.

1. Shimon Shetreet, Judicial Independence: New Conceptual Dimensions and Contemporary Challenges, in Judicial IndePendence: The Contemporary Debate 590, 593-94 (Shimon Shetreet \& Jules Deschenes eds., 1985). 
the United States judicial branch of government is more prominent than any other in the world. ${ }^{2}$ As the role of the courts increases, public scrutiny has also increased, and rightfully so. ${ }^{3}$ In a democratic society, judicial independence should be balanced with judicial accountability. ${ }^{4}$ This article concludes that there is a rational basis to believe that a number of policies, such as release of judicial data and judicial evaluations, would enhance judicial accountability without impacting judicial independence. In addition, judicial elections could be improved by providing relevant data on judicial performance and opinions of candidates on relevant issues.

While the role of courts in our society has at times been marked by restraint, it has also been prominently activist, alternatively on the liberal and then on the conservative side. On the one hand, restraint is reflected in the fact that, as of May 2000, only 158 of the many thousands of federal laws have been declared (at least in part) unconstitutional. ${ }^{5}$ On the other hand, the pace of such declarations has increased. Moreover, the number of decisions interpreting or reinterpreting the United States Constitution has remarkably increased in the last fifty years. ${ }^{6}$ Whether it is the rights of criminal defendants, abortion, freedom of speech, or school desegregation, courts have impacted and changed most aspects of contemporary society. ${ }^{7}$ A review of any major newspaper demonstrates the prominence of courts in our society. Whether the subject is the prosecution of a highly visible defendant for securities fraud or a civil suit for a mass oil spill, the courts have become more visible in the news than the legislative branch and at times even more visible than the executive branch.

2. Id. at 603-04; Peter H. Russell, Judicial Independence in Comparative Perspective, in Judicial IndePendence in the Age of Democracy 301, 302 (Peter H. Russell \& David M. O’Brian eds., 2001).

3. Russell, supra note 2, at 307; Paul D. Carrington \& Roger A. Cramton, Original Sin and Judicial Independence: Providing Accountability for Justices, 50 WM. \& MARY L. REV. 1105, 1107 (2009).

4. Carrington \& Cramton, supra note 3, at 1109.

5. Henry J. Abraham, The Pillars and Politics of Judicial Independence in the United States, in JUDICIAL INDEPENDENCE IN THE AGE OF DEMOCRACY, supra note 2, at 25,31 .

6. Archibald Cox, The Independence of the Judiciary: History and Purposes, $21 \mathrm{U}$. DAYTON L. REV. 565, 580-83 (1996) (discussing changes in judicial law-making during the Warren and Burger courts).

7. Id. at $580-81$. 
There can be no doubt that as the courts increase their prominence and influence they attract more critical commentary and increased effort to influence their decisions. ${ }^{8}$ With independence, judges may exercise appropriate discretion to determine the issues before them. Such independence allows judges to review actions of the legislative and executive branches of government as equal or even superior participants in government. Decisional independence allows judges to decide the individual matters before them free from the dictates of a legislature, an executive, the public, or the parties' extra-judicial influences. With judges less responsive to the democratic will, it is striking that American judicial prominence has been achieved in a society that prides itself, perhaps above all others, on adherence to democratic principles.

Most judges are first appointed to their positions. Once in their judicial positions, those who are subject to election are rarely defeated. ${ }^{9}$ Judicially created rules of conduct shield judges from ex parte influences so that any public influence on particular case decisions is limited. The goal of this independence is to provide neutral judicial decisions removed from political or public influence. $^{10}$ However, as independence increases, the impact of public opinion, as expressed by elected officials or the public directly, wanes. Judicial decisions can be made by an elite group of judges not subject to public review. Some commentators suggest that the answer to the potential of absolute judicial independence lies in judicial accountability. ${ }^{11}$ Judges must be accountable for judicial restraint, impartiality, and observance of society's needs.

8. Abraham, supra note 5 , at 33 .

9. Chris W. Bonneau \& Melinda Gam Hall, In Defense of Judicial ELECTIONS 9 (2009).

10. Martin H. Redish, Federal Judicial Independence: Constitutional and Political Perspectives, 46 Mercer L. Rev. 697, 707 (1995). But see Cox, supra note 6, at 567. Cox broadens the scope of judicial independence to include protection against executive oppression and protection for fundamental human rights. Id. at 567-71. The first relates to institutional independence, while both relate to a political position rather than a guarantee of decisional neutrality. Id. at 567-74.

11. Cox, supra note 6 at 567 ("The court must preserve its legitimacy and the ideal of law by invoking a majestic sense of continuity. At the same time, the law must coincide with the dominant needs and aspirations of its times. The dilemma is insoluble. By careful attention to the discipline of legal reasoning, a great judge can minimize the danger of writing personal values or preferences into decisions while also demonstrating that the new law, which the court must make from time to time, is linked to an inherited tradition."). 
In a democracy, however, accountability of public officials is ultimately to the electorate. If accountability is the restraint on judicial excess, how do we measure and then enforce that accountability? ${ }^{12}$ This article is an attempt to move toward a rational approach to judicial independence so that there are some mechanisms to measure and enforce accountability. First, I briefly review the history and purpose of judicial independence to demonstrate that there are appropriate limits. Second, the article explores the major democratic principles generally accepted by our society that conflict with the unfettered application of judicial independence. Finally, it explores some of the possible mechanisms for judicial accountability to determine whether they actually conflict with independence or neutral decision-making. This approach allows us to focus on some of the current aspects of our judicial system, often defended in the name of judicial independence, that impinge on democratic decision-making. The analysis, however, moves us toward a greater consensus because the twin goals of independent decision-making and democratic decision-making conflict on many, but not all, points. How we draw the appropriate lines will depend on the extent to which we value democratic versus neutral decisions. ${ }^{13}$ Looked at from another perspective, our boundaries for the degree of judicial independence will depend on our comfort with decisions made by a benevolent elite versus representatives highly responsive to the public will. Nevertheless, the analysis is useful because it allows us to isolate elements of the present judicial system that do not further the important interest of judicial independence. The analysis can bring into sharper focus the competing goal of democratic accountability allowing us to make more rational choices while discarding the notion that judicial independence is absolute.

12. See Shetreet, supra note 1, at 655 (discussing worldwide trends towards subjecting judges to greater scrutiny to improve judicial performance).

13. C. Neal Tate \& Torbjorn Vallinds, The Global Expansion of Judicial Powers 2 (1955); Brandice Canes-Wrone \& Tom S. Clark, Judicial Independence and Nonpartisan Elections, 2009 WIS. L. REV. 21, 23 (2009). 


\section{THE NATURE AND HISTORY OF JUDICIAL INDEPENDENCE PERMITS SOME REASONABLE CONCLUSIONS ON COMPETING GOALS}

The goals of judicial independence are both lofty and practically significant. At an institutional level we seek judicial independence so that the judicial branch can act as a check on the potential excesses of the legislative and executive branches of government. ${ }^{14}$ We balance that goal with the expectation that the executive and legislative functions will be able to curb excesses that may develop in the judicial system. At a decisional level, we promote judicial independence to achieve the goal of neutrality and fairness in individual case decisions. ${ }^{15}$ We seek not only neutrality in fact but the perception of neutrality so that the public can have confidence in our judicial system. At the same time we recognize that individual cases ultimately establish social and economic policy so that neutral decision-making must be responsive to the needs and desires of the society. ${ }^{16}$ In a democracy we believe the citizens should make important decisions through elected representatives who should be accountable to citizens for their decisions. ${ }^{17}$ There is an expectation that judges will be accountable for their performance while making neutral decisions. ${ }^{18}$ It is these potentially conflicting, laudable goals of independence and accountability that create the continued need to evaluate whether our judicial system is achieving the appropriate balance. $^{19}$

This article focuses on the decisional aspects of judicial independence rather than the institutional aspects. However, to clearly appreciate the policy factors that apply to decisional independence, it is necessary to review the interplay between institutional and decisional independence. Institutional independence allows judges to be free from undue influence by the

14. Charles Gardner Geyh \& Emily Field Van Tassel, The Independence of the Judicial Branch in the New Republic, 74 CHI.-KeNT. L. REv 31, 32 (1998).

15. Id.; Peter H. Russell, Toward a General Theory of Judicial Independence, in JUDICIAL INDEPENDENCE IN THE AGE OF DEMOCRACY, supra note 2, at 1, 10.

16. Abraham, supra note 5, at 34 .

17. Mauro Cappelletti, Who Watches the Watchmen? A Comparative Study on Judicial Responsibility, in JUdicial INDEPENDENCE: THE CONTEMPORARY DEBATE, supra note 1 , at 550,557 .

18. Id. at 550 .

19. See Shetreet, supra note 1, at 635-36. 
executive, legislative, and even elements of the judiciary. ${ }^{20}$ Decisional independence allows the judge to decide cases on a neutral and impartial basis free from undue influence by anyone, including the litigants, the executive, the legislative, and even, arguably, the public.

Independence from the executive branch of government requires that to a large extent judges not be dependent for their jobs, pay, and conditions of employment on the executive. ${ }^{21}$ To the extent the executive can reverse decisions of the judiciary, effective independence is threatened. If a judge is subject to removal by the executive on account of decisions, independence is impaired. Decisions by the executive about judicial pay or benefits will have a restraining impact on judicial independence. When we consider alternatives for judicial appointments, retention, and compensation, the choices allow the public, the executive, the legislature, or the judiciary to exert influence over the independence of the individual judge. ${ }^{22}$ Any system will allow some influence-the real question is the source and amount of influence permitted by the system.

Independence from the legislative branch of government can be negatively impacted where a judge's appointment, tenure, and pay are subject to legislative determination. ${ }^{23}$ Where the legislature controls the key elements that impact judicial performance, judicial independence will weaken. Independence from judicial system influence can be viewed as both an institutional and decisional aspect of judicial independence. Where judicial officers can determine the selection, tenure, and pay of the judges in the system, we can reasonably expect the judiciary to be able to present a stronger and even monolithic front to the other government branches and the public. On the other hand, judicial system control of the individual judge will negatively impact neutrality in individual decisions. ${ }^{24}$ If, because of control by superior judges, an

20. See ABA Comm. On SeParation of Powers \& Judicial IndePendence, AN INDEPENDENT JUDICIARY 5-6 (1997), available at http://www.abanet.org/poladv /documents/indepenjud.pdf [hereinafter ABA INDEPENDENT JUDICIARY].

21. See id. at 12-13 (explaining that federal judges were given a life tenure and a salary that could not be diminished to support their independence from the executive and legislative branches).

22. BONNEAU \& HALL, supra note 9, at 9; Russell, supra note 15, at 16 .

23. See Russell, supra note 15, at 25-28.

24. See David M. O'Brian \& Yasuo Ohkoshi, Stifling Judicial Independence from Within, in JUdiCIAL INDEPENDENCE IN THE AGE OF DEMOCRACY, supra note 2, at 37, 59; Shetreet, supra note 1, at 591. 
individual judge must decide each case in a prescribed manner, we will have achieved uniformity at the expense of neutrality. Where appellate review is unlimited and superior judges determine judicial assignments and initial or continuing appointment, uniformity of approach and cohesiveness are promoted over the goal of decisional independence..$^{25}$

Focusing on decisional independence, restrictions on the ability of the public to influence the courts will allow greater independence at the expense of judicial accountability and democratic control of decision-making. Likewise, restrictions on the ability of litigants to exercise extra-judicial influence over judicial decisions may enhance neutrality at the expense of freedom of speech. The absence of control over appointments, removals, reappointments, or pay by the executive, legislature, or judiciary itself will promote the goal of judicial independence. On the other hand, the absence of any control allows decisions to be made at the absolute whim of each individual judge. The individual judge is then subject to no controls other than his or her own sense of responsibility and fairness. The democratic control by citizens over judicial officials is absent.

To further understand the interplay of competing goals, it is necessary to appreciate the primary factors that can influence each aspect of judicial independence. The executive gains influence where it appoints judges, reappoints or removes judges, determines pay and benefits, funds the judicial system, and can effectively reverse its decisions. ${ }^{26}$ Similarly, the legislature asserts influence and reduces judicial influence where it controls appointment, retention, pay, funding, or can overrule judicial decisions. ${ }^{27}$ Individual judges can be strongly influenced by the judicial system itself through a broad appellate process of appointment, removal, and assignment authority. ${ }^{28}$

The extent to which any individual judge may need various protections to assure independence and neutrality will vary. Some judges are more easily influenced than others. At the one extreme are those who will provide neutral and fair decisions without any

25. See O'Brian \& Ohkoshi, supra note 24, at 37, 59.

26. See Leonard King, The IBA Standards of Judicial Independence: An Australian Prospective, in JUdicial IndEPENDENCE: The CONTEMPORARY DEBATE, supra note 1, at 403, 405-12.

27. Id.

28. Shetreet, supra note 1, at 637-43; see Russell, supra note 2, at 304. 
protections. ${ }^{29}$ On the other hand, some will be subject to effective influence even with lifetime appointments and guaranteed salaries. We should not design our systems for either extreme. We can expect that most judges should be relatively able to adhere to the accepted goal of fair and neutral decisions. Our systems should be designed for this great majority. We need not design a system with every conceivable protection when there are negative impacts from each limitation aimed at enhancing judicial independence.

The history of choices among alternatives in the United States reflects our own particular history, the interest in achieving a balance between competing branches of government, and decisions about competing policy goals. The provisions that created the judiciary in Article III of the United States Constitution are a reflection of the negative reaction to the King's appointment and removal of judges to maintain the Crown's policies. ${ }^{30}$ The Declaration of Independence complains of the operation of the colonial courts at the whim of the King. ${ }^{31}$ Article III of the United States Constitution assigned the judicial function to the courts. ${ }^{32}$ Judges are appointed for life. ${ }^{33}$ Their pay cannot be reduced during their tenure. ${ }^{34}$ Removal is only by legislative impeachment. ${ }^{35}$ On the other hand, the organization of the courts is left to the Congress, which may also determine the jurisdiction of courts of the United States. ${ }^{36}$ The courts have no independent means of enforcing their orders and must ultimately rely on the executive branch for that purpose. ${ }^{37}$ While appointment authority was jointly vested in the legislative and executive branches, it does not appear that serious thought was given at the creation of the Constitution as to whether courts should be independent from the people. ${ }^{38}$ Over the intervening years we have seen removal by impeachment rarely used and, while occasionally threatened based upon the apparent merit of a particular judicial decision, never actually used in this

29. Russell, supra note 15 , at 6-7.

30. Shetreet, supra note 1, at 603; Manfred Simon, The Role of Judges in a Rapidly Changing Society, in Judicial IndePendence: The Contemporary Debate, supra note 1, at 546, 556; Cox, supra note 6 , at 570 .

31. THE DECLARATION OF INDEPENDENCE para. 11 (U.S. 1776).

32. U.S. CONST. art. III, $\$ 1$.

33. Abraham, supra note 5, at 26.

34. U.S. CONST. art. III, $\$ 1$.

35. Id.; see also Abraham, supra note 5, at 26.

36. U.S. CONST. art. III, $§ 2$.

37. U.S. CONST. art. II, $\$ 1$.

38. Geyh \& Van Tassel, supra note 14, at 36. 
way. ${ }^{39}$ Courts of the United States have developed a complex appellate review system that promotes uniformity of law but generally allows individual judges discretion on fact-finding in individual cases. $^{40}$ Similarly, a complex judicial administrative system has developed that may impact assignments of particular judges. $^{41}$

The pattern with state courts and independence is more complex. Initially some state constitutions provided that judges were appointed and retained by executive or administrative agencies. ${ }^{42}$ In the 1830 s dissatisfaction developed with this method and more states provided for either initial election or retention elections after limited appointed terms. ${ }^{43}$ Generally, state court budgets and the jurisdiction of state courts is determined by the legislature. Most often, initial appointments of judges are determined by the governor with the advice of a selection commission. $^{44}$ Over the last thirty years there has been some negative reaction to elections with fewer states providing for partisan elections and some states moving to retention elections. ${ }^{45}$ All state court systems have complex appellate review rules to facilitate uniformity of law. ${ }^{46}$ They also often have administrative systems that allow for assignment of judges by superior judicial officers. Through codes of judicial conduct, state courts limit the extrajudicial influence of litigants and the public on individual decisions. ${ }^{47}$ The history of federal and state court creation does not provide clear answers to today's issues of judicial independence and accountability because contemporary issues were not significant or were given little attention during constitutional conventions. ${ }^{48}$

39. Abraham, supra note 5 , at 26.

40. Fed. R. Civ. P. 52(a) (6); Richard D. Freer, Civil Procedure, 805-10 (2d ed. 2009).

41. See Shetreet, supra note 1, at 644-45.

42. Robert B. McKay \& James M. Parkison, United States of America, in Judicial INDEPENDENCE: THE CONTEMPORARY DEBATE, supra note 1, at 358, 360.

43. BONNEAU \& HALL, supra note 9, at 5-9; Shetreet, supra note 1, at 603.

44. Shetreet, supra note 1 , at 603.

45. BONNEAU \& HALL, supra note 9, at 3 .

46. See generally MinN. R. Civ. APP. P. (illustrating the complexities of rules directed toward appellate review).

47. See, e.g., Model Code of Judicial Conduct R. 1.3, 2.4, 3.1, 3.3, 4.1, 4.2, 4.4 (2008).

48. Geyh \& Van Tassel, supra note 14, at 40-56. 
There are significant countervailing goals negatively impacted by some policies that promote judicial independence. On an institutional level, a strong judiciary may remove important public policy decisions from the elected representatives of the citizens and provoke criticism. ${ }^{49}$ Where judges, independent of citizen control, make decisions on reproductive rights, rights of criminal defendants, or desegregation, the democratic process is significantly impacted. ${ }^{50}$ Where citizens are unable to effectively voice a position on important issues coming before the courts, democratic ideals are challenged, and freedom of speech and the right to petition the government suffers. Where judges shield their performance from public view, the democratic ideal of public officials' accountability is challenged.

This brief overview of the history and the elements impacting judicial independence allows a number of reasonable conclusions that should influence the current debates over judicial independence. First, in both theory and practice, judicial independence, whether institutional or decisional, has never been treated as an absolute. ${ }^{51}$ Those who argue that judicial independence demands a certain result, without consideration of the competing interests, are wrong on both a theoretical and practical level. The issue of judicial independence requires a weighing of competing interests rather than single-minded obedience to a particular talisman. ${ }^{52}$ Second, judicial independence is not an end in itself. ${ }^{53}$ The actual goal is neutral

49. See, e.g., ABA INDEPENDENT JUDICIARY, supra note 20, at vi (presenting a critique of the Supreme Court's handling of line item veto legislation passed in 1997).

50. See Shetreet, supra note 1, at 656 .

51. See Russell, supra note 15, at 12; see also World Conference on the Independence of Justice, Universal Declaration on the Independence of Justice, in JUdiCIAL INDEPENDENCE: THE CONTEMPORARY DEBATE, supra note 1, at 447, 448-50 [hereinafter World Conference]. But see The Constitution Project, The Newsroom Guide tO JUdicial IndePENDENCE 3 (2006), available at http://www.constitutionproject.org/pdf/37.pdf ("We believe judicial independence can only be achieved when judges have the freedom to make decisions according to the law, without regard to political or public pressure, which allows them to protect the basic rights to individuals and decide cases fairly.").

52. See Cappelletti, supra note 17, at 555-57; Shetreet, supra note 1, at 635-36.

53. Cappelletti, supra note 17 , at 556 ("Judicial independence (from the executive) is itself anything but an ultimate value; far from being an end in itself . . ..”); Russell, supra note 2, at 301, 303 (discussing other countries' approaches to the problem of judicial independence and accountability). 
decision-making. ${ }^{54}$ In considering any of the policies or programs that may relate to judicial independence, the most pertinent question is the impact on neutral decision-making. Third, as a corollary to this last point, the doctrine of judicial independence is for the benefit of the public and not for the benefit of judges. ${ }^{55}$ Arguments that a particular policy will make the judicial function more difficult for judges and thus undercut judicial independence are not rationally related to the ultimate goal of neutral decisions.

Fourth, the tools or policies to promote neutral decisionmaking are of different strengths, and the impact of different tools or policies on the competing goals vary considerably. For example, lifetime appointments do more to insulate a judge from both individual case and institutional pressure than any other device. ${ }^{56}$ At the same time, lifetime appointments remove most aspects of democratic accountability and permit significant discretion unencumbered by a need to follow the popular will. ${ }^{57}$ Finally, there is no way to measure the actual effect of many of the elements of judicial independence on the ultimate goal of neutral decisionmaking. We do not necessarily agree on what is a neutral decision, and the many variables impacting any judicial decision make measurement of neutrality impossible. Similarly, it is impossible to determine the negative impact of many of these policies on accountability or democratic decision-making. Logic will often tell us the probable impact of a policy, but it will give us little information of its magnitude. This doesn't mean we can avoid making judgments because in this area not making a judgment is to make a judgment. The status quo is not stationary. Both new laws and court decisions continually modify the authority and independence of judges. We should all recognize, however, that dogmatic certainty on this subject is inappropriate. In many aspects of this issue, neither history nor data provides clear answers.

54. See World Conference, supra note 51, at 12.

55. See Cappelletti, supra note 17, at 556.

56. See World Conference, supra note 51, at 14. See generally Carrington \& Cramton, supra note 3, at 1108 (outlining the historical progression of managing judicial independence).

57. See generally Russell, supra note 15, at 5 (citing perspectives of various authors regarding the independence of judges and lawyers). 


\section{AN APPLICATION OF GENERALLY ACCEPTED PROPOSITIONS TO SEVERAL CONTEMPORARY ISSUES ALLOWS REASONABLE CONCLUSIONS}

Having recognized the difficulty of making absolute judgments in this area, the five relatively uncontroversial points outlined above provide a basis for reasonable conclusions on some practices associated with judicial independence or neutral decision-making. First, consider some of the practices impacting individual litigants. The judicial codes and the rules of professional responsibility prohibit litigants and judges from having ex parte communications regarding the merits of cases before them. ${ }^{58}$ These rules serve an important function in preserving neutral decision-making. The judge hears from the parties on all pertinent issues in the presence of all parties. The litigants can believe the judge is neutral and not subject to "influence" outside their presence. The rules do restrict freedom of speech and the right to petition, but the restriction is limited and reasonable. Other court rules guarantee the parties the opportunity to provide the court with all pertinent information and argument as long as those arguments are made available to all parties. $^{59}$

Judges enjoy absolute immunity from damage suits for any action taken even arguably within their jurisdiction. ${ }^{60}$ Clearly, this serves an important purpose in allowing judges to make fair and neutral decisions. If a judge is worried about one party or another bringing suit, it may impact the judge's decision. Certainly the threat of suit would create the perception that a judge could be influenced by the possibility of litigation and expense from suit. This immunity doctrine, however, runs counter to the notion of accountability. ${ }^{61}$ Some persons harmed by a judicial action will be without a remedy. Judicial immunity is broader than the qualified

58. Model Code of Judicial Conduct Cannon 2.9 (2008); Model Rules of Prof'L ResPonsibility Cannon 7, DR 7-110(B) (2008).

59. E.g., FED. R. CIV. P. 5 (a) (1), 43(a).

60. See, e.g., Stump v. Sparkman, 435 U.S. 349, 357 (1978) (stating that a defendant judge is only subject to liability "in the clear absence of any jurisdiction"). The facts of this case are particularly egregious. A 15-year-old was ordered to undergo a tubal ligation without prior notice or a subsequent opportunity to appeal. In fact, she wasn't told the nature of the medical procedure until long after the fact. Id. at 351. See also Bradley v. Fisher, 80 U.S. 335, 336 (1871).

61. Cappelletti, supra note 17 , at 554-56. 
immunity provided to most members of the executive branch. ${ }^{62}$ Unfortunately, the doctrine is for the most part created by judges for the benefit of judges. While no man should be the judge of his own case, this particular doctrine is appropriate. ${ }^{63}$ The harm to the decision-making process by suits against judges would be great. The time spent responding to such suits would interfere with performance of judicial duties. The negative impact on accountability is minimized by several well-established rules of judicial procedure. First, the appellate procedures that are nearly always available in our courts provide recourse for misapplication of the law and arbitrary conduct by lower courts. Second, the opportunity for adversarial presentation of facts and arguments most often prevents the worst excesses that can come from a purely one-sided presentation. While it is true that a few people are harmed by judicial immunity, and it is difficult to know how many, the relatively few reported cases or press accounts suggest the number is few. If we were to modify the rule to only provide qualified immunity to judges, we could expect regular suits, like we see against executive branch employees, testing whether the judge acted just negligently or in deliberate disregard of the law. ${ }^{64}$ The harm from such suits would outweigh the damage that may be done in the very few cases that might ultimately survive a qualified immunity standard. ${ }^{65}$

Financial relationships between judges and litigants present a more complicated factual picture but one that requires more stringent rules than we have at present. In federal courts, rules require litigants to disclose significant corporate ownership. ${ }^{66}$ Federal judges disqualify themselves when they have a financial interest in a party that "could be substantially affected" by the matter. ${ }^{67}$ State court judges may also have investments in corporations that come before them. Many state court judges receive campaign contributions from attorneys, litigants, and potential litigants. The ABA Model Code of Conduct provides that

62. See Frank Way, A Call for Limits to Judicial Immunity: Must Judges be Kings in Their Courts?, 64 JUDICATURE 390, 396 (1981) (arguing for limits on judicial immunity).

63. Id.

64. See generally Pullian v. Allen, 466 U.S. 522, 551-53 (1984) (discussing some of the limits of judicial immunity).

65. See Stump, 435 U.S. at 363-64; Bradley, 80 U.S. at 354.

66. FED. R. CIV. P. 7.01.

67. 28 U.S.C. $\$ \$ 455$ (b) (4)-(5) (2006). 
a judge should self-disqualify when he or she has an economic interest in a party that is more than de minimis and may be affected by the outcome. ${ }^{68}$ The model code also suggests that judges be disqualified when the judge knows a party or a party's lawyer has made a recent campaign contribution. ${ }^{69}$ No trigger amount is suggested in this model rule. These proposed rules are not sufficiently clear and the campaign contribution provision has not been generally adopted by the states. ${ }^{70}$ The United States Supreme Court recently held that where an owner of a corporation made contributions of over three million dollars to a state supreme court justice's campaign, due process required the justice recuse himself. $^{71}$ The decision notes that states are free to adopt more restrictive measures. $^{72}$

We all appreciate that a financial interest provides a strong incentive that influences behavior. Both the reality and appearance of neutral justice are adversely impacted where a judge has an economic interest in a party or has received any significant campaign contribution from a party or a party's attorney. It is inappropriate to ask judges to avoid any financial investments and we may not constitutionally prohibit campaign contributions by lawyers and potential parties. However, we can require judges to recuse themselves when they or their immediate family have a financial interest in a party or they received more than a de minimis (say one hundred dollars) campaign contribution toward their last election campaign from a party, an attorney, or a single interest advocacy group appearing before them. By requiring disqualification for any material economic interest, we can preserve the benefits of both judicial neutrality and freedom of speech in campaigns. The seriousness of the impact on the reality and appearance of neutrality caused by a judge's conflicting financial interests requires clear rules prohibiting these obvious conflicts. The minor difficulty of finding alternate judges when there is a recusal is not significant compared to the negative impact of

68. Model Code of Judicial Conduct Canon 2.11A(3) (2008).

69. Id. at Canon 2.11A(4).

70. See Bert Brandenburg, Inevitable, Flexible, Expandable Caperton?, 33 SeAttle U. L. Rev. 617, 624 (2010) (exploring the implications of Caperton $v$. Massey, 129 S. Ct. 2252 (2009), which involved a Virginia Supreme Court justice who refused to recuse himself from a case despite receiving the majority of his election campaign funds from one of the litigants).

71. Caperton v. A.T. Massey Coal Co., 129 S. Ct. 2252, 2266-67 (2009).

72. Id. 
allowing judges with economic interests to decide cases. The inconvenience or annoyance to the judge in keeping track of economic conflicts does not approach the damage to the fact and appearance of neutrality caused by significant economic conflicts.

Occasionally the claim is made that criticism by litigants or their attorneys impinges on judicial independence. ${ }^{73}$ We should reject this suggestion. It is the essence of freedom of speech to be able to comment on the actions of government officials. ${ }^{74}$ The Model Code of Professional Conduct permits criticism of judicial conduct as long as it is not knowingly false or reckless regarding the integrity or qualifications of a judge. ${ }^{75}$ After a case is concluded, critical comment is highly unlikely to impact the outcome. Judges should be open to criticism. ${ }^{76}$ Some criticism may serve to improve performance. While some argue that judges should only be subject to "fair" criticism, the fact is we will not all agree on what is "fair." Rather than regulate criticism by its fairness, all discussion should be permitted and the public can sort out what is correct. Even critical public comment during a proceeding by a party, while most likely ill-advised, should not be considered an improper intrusion on judicial independence. ${ }^{78}$ If the comment is seen or heard by the judge, it can be brought to the attention of all parties for appropriate response. The adversary system can function effectively and freedom of speech is preserved. ${ }^{79}$

There are a number of issues related to judicial independence that impact the public, beyond solely the litigants. The resolution of some of these issues is also aided by a full understanding of the purposes of judicial independence and an analysis of the particular issue in light of competing goals. Courts have available, or could have available, a myriad of statistics on judicial performance. Straightforward information on judicial workload and attendance is significant to an evaluation of judicial performance. The number or percentage of appeals, affirmances, and reversals is relevant to

73. See ABA INDEPENDENT JUDICIARY, supra note 20 at 19-20.

74. See generally New York Times Co. v. Sullivan, 376 U.S. 254 (1964) (noting the importance of providing safeguards for freedom of speech and freedom of the press in a defamation case brought by a public official against critics of his official conduct).

75. Model Code of Prof'l Responsibility DR 8-102(B) (2008).

76. See Shetreet, supra note 1, at 656 .

77. See id.

78. See Russell, supra note 15, at 21-22.

79. See ABA INDEPENDENT JUDICIARY, supra note 20, at i, vi (noting that judicial independence should not be used to stifle criticism of judicial conduct). 
an evaluation of a judge's willingness and ability to follow the law. Recusals or party removals may provide useful information on a judge's ability or fairness as perceived by litigating parties. Surprisingly, much of this information is often difficult to obtain. The argument for withholding this information is very weak. The data may be subject to misinterpretation, as is most data, but the court or judge will have the opportunity to provide an accurate interpretation.

On the other hand, this data is clearly relevant in assessing performance. While the data may suggest a judge is doing a good or poor job, it is highly unlikely to bear on the merits of any future decision. The data may be embarrassing to a particular judge, but the purpose of judicial independence is not served by avoiding embarrassment of particular judges. To foster democratic accountability of judges, the public dissemination of performance data is critical. Whether judges are appointed or elected, the public should have good information on the performance of important public officials. The argument that the data may be misunderstood by the public is inconsistent with democratic principles. The federal government and most states have "freedom of information" acts which grant citizen access to most executive data. ${ }^{80}$ There is a need for established mechanisms to disseminate information on judicial performance.

Many of the same arguments relate to the more explosive issue of judicial evaluation. ${ }^{81}$ While some judges have been supportive of judicial evaluation, many have opposed these programs claiming they will interfere with judicial independence or will not be properly understood by the public. ${ }^{82}$ Evaluation programs have sought information from people with experience before the judge: parties, lawyers, or court personnel. The best evaluation programs ask about the judge's work habits, knowledge of the law, treatment of litigants, and perceived fairness. Most professionals, including doctors and lawyers, are constantly evaluated. Judges should accept

80. E.g., Freedom of Information Act, 5 U.S.C. $§ 552$ (2006); MinN. STAT. $\S \S$ 13.01-13.90 (2008).

81. See David C. Brody, The Use of Judicial Performance Evaluation to Enhance Judicial Accountability, Judicial Independence, and Public Trust, 86 Denv. U. L. Rev. $115,155-56$ (2008) (summarizing the importance of judicial performance evaluations).

82. See Russell, supra note 15, at 19; Richard B. Hoffman \& Frank P. Cihlar, Judicial Independence: Can It Be Without Article III?, 46 MERCER L. REV. 863, 879-80 (1995) (discussing the history and impacts of judicial performance evaluation). 
evaluation programs as a reasonable aspect of judicial accountability. There is no better method available to provide the public with information on judicial performance. The impact of public access to this information will reward some judges by highlighting their superior performance. Others may feel threatened for fear of a poor evaluation or embarrassed by the public release of bad marks. However, there is no rational basis to suggest good or bad evaluation results will impact the merits of a subsequent decision. ${ }^{83}$ The results may cause the judge to reflect on his or her diligence, fairness, and preparation, but that is for the public good. Democratic accountability is promoted by the availability of evaluation data on judicial performance. ${ }^{84}$ There is no reasonable basis to argue that public evaluation will significantly impact neutral decision-making.

Where judges are elected, performance data, such as evaluation results, is critical to an informed electorate. ${ }^{85}$ Some judges and lawyers complain that voters are uninformed in judicial elections. ${ }^{86}$ It is the courts and lawyers who fail to provide pertinent data that would inform the public. As lawyers and judges, we have the means to provide the data on which the public could make more meaningful choices in judicial elections.

A judge with good evaluations is unlikely to be opposed in the next election, while one with poor evaluations is more likely to be opposed. The judge drawing an opponent may be inconvenienced, but the process promotes public accountability and a meaningful democratic election process. Where judges are selected for life, as in the federal system, meaningful public evaluation is totally absent, but very necessary. A lifetime judicial appointment is clearly the most powerful available tool promoting judicial independence. ${ }^{87}$ At the same time, it has a negative impact on the goals of accountability and democratic responsiveness. Beyond appeals, an

83. See Russell, supra note 15 , at 19 (discussing the use of public complaints, reprimands, and "sensitivity training" as part of an evaluative process, but noting that judicial independence can be retained throughout such procedures).

84. See id.

85. William R. Anderson, Judicial Selection in Washington-Taking Elections Seriously, 33 Seattle U. L. Rev. 605, 612 (2010) (discussing the need for inclusion of performance and other data to empower a meaningful election process for judges); Brody, supra note 81, at 118.

86. See BONNEAU \& HALl, supra note 9, at 2.

87. See The Federalist No. 78 (Alexander Hamilton); cf. Carrington \& Cramton, supra note 3, at 1108-09 (discussing the use of removal and disciplinary proceedings to enhance accountability). 
occasional media story, or a litigant's comments, there are few restraints-other than self-restraint-on the discretion and behavior of those with lifetime appointments. ${ }^{88}$ Public judicial evaluation of judges with lifetime appointments will have little impact on the merits of decisions by someone so insulated from negative consequences. It can advance the goals of democratic accountability by providing some public consequences for the best or worst judicial behavior. It can also provide encouragement for more positive judicial behavior.

The increasing presence of citizen advocacy groups in our courtrooms has led to negative comments from some judges. These groups range from better government coalitions to groups stridently advocating particular case outcomes. Whether it is the League of Women Voters or Mothers Against Drunk Driving (MADD), these groups operate on well-traveled roads protected by First Amendment rights of freedom of speech and petition. Those critical of organized public advocacy argue that the presence of these groups in the courtroom and their public comments will influence the judge and thus impact judicial neutrality. This situation brings into sharper focus competing goals because the very purpose of the group activity may be to influence judicial action. These groups are often seeking to impact both the manner of judicial performance and the case outcome. But consider the importance of the competing values and the actual impact of the activity on those values. These First Amendment rights are among our most cherished. What does it say about our judicial system if we forbid citizens to have a voice that can be heard? The impact on judicial neutrality from accepting these groups in our courtrooms is not nearly as severe as barring constitutionally protected conduct. Comment from these groups is very public and the litigants have a full opportunity to respond to it.

Finally, these citizens groups do not have a strong negative impact on judicial neutrality. First, many of these groups focus on the quality of performance rather than the outcome, so there is little impact from their activities on the merits of the decision. ${ }^{89}$

88. See Gordon Bermant \& Russell R. Wheeler, Federal Judges and the Judicial Branch: Their Independence and Accountability, 46 MERCER L. REV. 835, 843 n.33 (1995) (showing the effects of the Judicial Councils Reform and Judicial Conduct and Disability Act of 1980 on judicial independence; suggesting that there are little or no repercussions, in most cases, upon the filing of a judicial complaint).

89. See, e.g., League of Women Voters, About the League, http://www.lwv.org /AM/Template.cfm?Section=About_Us (last visited Jan. 20, 2011) (explaining that 
Second, other groups focus on relatively broad but important societal issues-e.g., the incarceration rate for drunk drivers, the allowance of abortion, or the treatment of victims or perpetrators of domestic violence. ${ }^{90}$ Simply by deciding cases, any judge whose responsibility includes these matters will have a developed view of the appropriate policy, and the judge will apply that view to the individual facts of the next case. The petitioning group often seeks to change that judicial view and have the judge adopt a different policy. In this regard, the judge is no more neutral at the policy level than is the petitioning group. For the goal of neutrality, there is little benefit to be obtained by restricting these petitioning activities; however, the restrictions would be a huge loss to democratic goals.

The potential of cameras in the courtroom sometimes provokes the response that their presence will impact judicial independence. Certainly other arguments are made as well, including those that it will harm witnesses or jurors, be inconvenient, or further sensationalize the more emotional cases. Focus on only the judicial independence argument demonstrates that it can provide little support for those opposing cameras in the court. The camera reveals courtroom conduct. It rarely shows results, but when it does, the revelation of the result is hardly more than would be apparent on the evening news or the morning paper. However, for the truly interested citizen, the camera will show how the system and its participants actually worked-or did not work. If we accept the principle that an informed citizenry is important to our democracy, then cameras in the courtroom are significant in achieving this important goal. ${ }^{91}$ The quality of our judicial procedures is important and there is no better way-or perhaps, no other way-to display it to the public than cameras in the courtroom.

the League attempts to "influence policy through advocacy" in a nonpartisan manner and noting that its basic purpose is to "make democracy work for all citizens," thereby suggesting that a predetermined outcome is not the ultimate goal).

90. See, e.g., MADD, Mission Statement, http://www.madd.org/about-us /mission/ (last visited Jan. 20, 2011) ("The mission of Mothers Against Drunk Driving is to stop drunk driving, support the victims of this violent crime and prevent underage drinking.").

91. See Steven Brill, Courtroom Cameras, 72 Notre Dame L. Rev. 1181, 1192 (1997). 


\section{THE PRACTICAL LIMITS ON THE CONCEPTS OF JUDICIAL INDEPENDENCE AND ACCOUNTABILITY HAVE A BEARING ON OTHER CONTEMPORARY ISSUES}

The very notion of judicial neutrality is far from straightforward. The image that a judge comes to an individual case without a pre-formed opinion is strikingly naive. Any judge who had a prior opportunity to hear a similar matter has certainly formed opinions about issues such as abortion, the general rate of incarceration, and many other similar issues. Judges are exposed daily to opinions on issues from television, newspapers, law review articles, and friends. ${ }^{92}$ To pretend that judges or potential judges are neutral on these kinds of issues, so that judicial independence must be adjusted to protect this presumed neutrality, is to distort the need for and importance of the principle of judicial independence.

The days when one could argue that the process of judging was to apply clear law to apparent and undisputed facts are long gone. ${ }^{93}$ With regard to the law, we know that on the appellate levels there are often majority and dissenting opinions. The judges disagree on what the law is or ought to be. We often are able to identify liberal and conservative judges who bring a pre-formed political view to the process, resulting in different judgments on individual cases. In the continuing litigation over the constitutionality of the recent healthcare legislation, public comment notes that two federal district court judges appointed by Democrats have held the law constitutional while two appointed by Republicans have held it unconstitutional. ${ }^{94}$ It should be no surprise that presidents and governors often appoint persons of their own party to important judicial positions. ${ }^{95}$ These politicians know that the political views of their appointees are likely to influence their decisions in important cases. ${ }^{96}$ Interest groups, political groups, and ethnic groups all strive mightily to have persons of like minds or backgrounds appointed to the courts. They know that decisions from members of their group are likely to

92. Russell, supra note 15 , at 12 (noting the various influences that constantly impact a judge, including legal scholars and colleagues, and the fact that they cannot all be avoided).

93. See Abraham, supra note 5, at 33-34; Cappelletti, supra note 17, at 572-73.

94. Dead or Alive, The Economist, Feb. 5, 2011, at 37.

95. See Russell, supra note 15 , at 16.

96. BONNEAU \& HALL, supra note 9 , at 14. 
reflect the group's interest and values. Savvy lawyers, when given the opportunity to choose or remove a judge, will identify judges who side with the prosecution, the criminal defendant, the injured plaintiff, or the corporate defendant, and act accordingly.

Disputed facts are also not subject to one neutral interpretation. Even where a judge has not formed a settled judgment on a matter of policy, the judge's background will influence each factual decision. While we have many shared influences with different social, ethnic, religious and education backgrounds, we also have different influences that will impact our judgments about particular litigants and fact situations. ${ }^{97}$ In many cases there is not a single neutral factual outcome on which we can all agree. The law has developed a nearly universal principle of appellate review that recognizes this phenomenon: we review a trial judge's findings of fact to determine whether they are clearly erroneous. ${ }^{98}$ In other words, we recognize that there is a range of outcomes in a contested case dependent on which witness is believed or which piece of evidence is given the most emphasis. Our backgrounds, and at times our ideology, will influence these choices.

This does not mean the goal of neutrality is unimportant. The goal is worthwhile because there is a need for litigants to have confidence in our dispute resolution system. Most judges will strive to be impartial and render fair and neutral decisions. We must judges making purely political judgments or fact-finding based on personal bias. The goal of neutrality keeps our system viable as one that is generally perceived to reach fair results. It is no surprise that among all of our institutions, the courts have historically been regarded by the public as having the greatest credibility. A goal that is ultimately unattainable is still worth pursuing for the good it achieves. Nevertheless, in evaluating the need for judicial independence we should not assume that providing all of the available protections will result in either non-political lawmaking or unbiased fact-finding. We are likely to need mechanisms that restrain both lawmaking and biased fact-finding even if those mechanisms modestly constrain judicial independence.

97. Id. at 2 .

98. FreER, supra note 40, at 806-07; James Zagel \& Adam Winkler, The Independence of Judges, 46 MERCER L. REV. 795, 804-05 (1995). 
A corollary to this point is the fact that some judges are more willing or able to control personal or political inclinations than others. Many judges ardently seek to repress their own views and treat litigants truly as equals. ${ }^{99}$ However, other judges, both at the trial and appellate levels, rejoice in their personal worldview and seek to impose it on all who come before them. For this latter group, we cannot assume neutral behavior and we must have systems that will restrain such behavior even if it impinges on judicial independence.

The fact that there are political decisions, neutral decisions, biased findings, fair findings, judges who strive toward neutrality, and others who don't, cannot be disputed. However, we will not agree on the degree of politics, bias, or neutrality operating in our system. There is no way to measure these tendencies since we will not all agree on what constitutes a neutral decision versus a biased or political one. We can move toward a rational analysis by recognizing that the goal of neutrality is unattainable and a system needs other devices to assure fair results. A system that allowed complete independence would not restrain those who would fully exercise their own personal or political views in making decisions. While absolute independence is inappropriate, there is little consensus on the best ways to effectively constrain its negative effects while preserving its most important attributes-actual and perceived neutrality. ${ }^{100}$

If neutrality is a goal, and difficult to define, then so is accountability. What do we ask judges to be accountable for? Who is to determine whether judges have achieved adequate neutrality? And what do we do about any conclusions? Again, there are some aspects of accountability that are relatively clear and allow reasonable conclusions. A judge should be accountable for a reasonable work effort. Statistics should be made available from which that determination can be made. Although we may differ on the boundaries of a reasonable effort, agreement can be expected on outliers. The judicial code provides a basis to hold judges accountable and can reasonably result in private discipline or public reprimand. Evaluations by lawyers and litigants, when directed at the more objective aspects of performance rather than

99. Cox, supra note 6 , at 583-84.

100. See, e.g., Irving R. Kaufman, The Essence of Judicial Independence, 80 Colum. L. REV. 671, 671-72 (1980) (opposing even modest disciplinary procedures for federal courts). 
merits, provide reasonable information for accountability.

Other aspects of the quality of a judge's performance are much more difficult to measure. The issue of "quality" in decisions often shades into discussions of "activism" and the politics of decisions. Certainly for judges whose decisions are regularly reversed on appeal as contrary to law or arbitrary, it is reasonable to make a judgment about the quality of judicial performance. The extent to which the politics of decisions should be a part of an accounting is far more controversial. On the one hand, we ask judges as a part of a commitment to neutrality to put politics aside. As part of an accounting, there ought to be a way to assess whether a judge has lived up to that commitment. On the other hand, we know that many decisions involve a political aspect. To hold a judge accountable in those situations will impinge on judicial independence. In a reasonable attempt to hold judges accountable, we should ensure that data is available on those aspects of performance that relate to work efforts, code compliance, and record on appeal. This information provides a reasonable basis for an accounting without significant intrusion on judicial independence.

\section{DISSECTING THE DEBATE OVER ELECTIONS, APPOINTMENTS, AND REMOVAL OF JUDGES IN THE CONTEXT OF JUDICIAL INDEPENDENCE DEMONSTRATES THAT MODEST ENHANCEMENTS CAN REMEDY MORE COMPLAINTS ABOUT ELECTIONS}

The two prominent forms of judicial selection are lifetime appointment with removal only by impeachment and executive selection with reelection to limited terms. The federal system employs lifetime appointments, while most states use some form of appointment/election combined with limited terms. The federal system clearly offers the most support for judicial independence. Removal is constitutionally limited to departure from "good Behaviour." " This stringent standard plus the difficulty of organizing a congressional impeachment proceeding have resulted in the impeachment of few federal judges in our nation's history. ${ }^{102}$ Despite occasional threats from irate congressmen, there is general

101. U.S. CONST. art. III, $§ 1$.

102. See ABA INDEPENDENT JUDICIARY, supra note 20, at 47-49, 67, 80-81; Abraham, supra note 5, at 26. 
consensus that it is inappropriate to use impeachment to remove a judge because of disagreement with the judge's decisions. ${ }^{103}$ Historically, impeachment had little, if any, impact on judicial independence, but also provided no significant enhancement to accountability. Lifetime appointments are favored by those who believe that decisions by an educated elite are an appropriate balance to the other two branches that are more democratically responsive. Lifetime appointments clearly achieve a high level of judicial independence at the expense of accountability.

Federal judges' independence is subject to limited constraints. Trial judges are subject to the constraints of appeals. Appeal procedures effectively impose a relatively uniform set of laws and court-made rules on trial courts. ${ }^{104}$ With a more limited scope of appeal for factual findings, trial court factual conclusions are subject to fewer constraints. Appeal constraints apply less to appeals court judges and not at all to United States Supreme Court Justices. In our federal system, additional constraints exist including the ethos of fair and impartial behavior, stare decisis, peer pressure, and public criticism. Appointments of federal judges clearly reflect the politics of the current president. However, the confirmation proceedings are often characterized by a refusal to answer questions about the candidates' position on the most debated political issues of the day or the surprising claim that the candidate has formed no opinion on that important political question. ${ }^{105}$

Particularly at the Supreme Court, the politics of decisions is clearly apparent. In Bush v. Gore, the Court decided a most political question in a very political manner. ${ }^{106}$ In Citizens United v. Federal Election Commission, the Supreme Court majority invalidated, on constitutional grounds, limitations on corporate campaign spending that had passed muster in a number of prior recent Supreme Court decisions. ${ }^{107}$ The dissent emphasized the point:

103. See Cox, supra note 6, at 574-80.

104. See, e.g., Bermant \& Wheeler, supra note 88, at 840 ("[L]egal and institutional constraints . . . discourage independent judges from doing anything they please.").

105. See Peter David, USS Kagan Prepares to Set Sail, The Economist, July 1, 2010, available at http:/ / www.economist.com/node/16481611.

106. 531 U.S. 98 (2005) (effectively resolved the 2000 presidential election in favor of George W. Bush holding that manual recount to meet "safe harbor" deadline was unconstitutional).

107. 130 S. Ct. 876 (2010). 
"The only relevant thing that has changed since Austin and McConnell is the composition of this Court."

It is a mistake to decide whether this degree of independence is appropriate based on one's ideology. Certainly there have been periods, such as the Warren Court, that advanced a liberal agenda with decisions on desegregation and defendants' rights. Conservatives railed against a liberal activist Court. But activism is not the exclusive purview of the liberals. In the mid-1930s, conservatives on the Supreme Court sidetracked much of the early New Deal legislation on constitutional analysis that seems weak in retrospect. ${ }^{109}$ Today, a more conservative Court regularly prompts claims of conservative lawmaking from liberal politicians and the press. ${ }^{110}$ The Court has at times stood in the way of progressive positions that are now widely accepted. On other occasions, it has been the one branch of government that moved us toward progressive results, some of which are widely accepted today, while others continue to spark controversy. ${ }^{111}$

Whatever your view of lifetime tenure and its significance for judicial activism, there is no likelihood of these constitutional provisions changing. To constrain activism and restrict naked political judgments, there are reasonable, but modest, steps to take. First, we must continue to expect our federal judges to have neutrality and impartiality as a goal. This is a reasonable expectation for which all judges should be held accountable. ${ }^{112}$ While recognizing that precedent must bend with changing times, we should emphasize that stare decisis has great value because it permits reasonable expectations of what the law will be. ${ }^{113}$ It promotes the important perception that there is a neutrality to the application of law that is above the unconstrained will of the judge. ${ }^{114}$

108. Id. at 942 (Stevens, J., dissenting).

109. See, e.g., R.R. Ret. Bd. v. Alton Ry. Co., 295 U.S. 330 (1935) (applying a narrow view of the Interstate Commerce Clause).

110. See, e.g., David, supra note 105, at 1; Sheryl Gay Stolberg, Obama Blasts High Court Ruling, N.Y. Times Dig., Jan. 24, 2010, at 3; Editorial, The Court's Aggressive Term, N.Y. Times, July 4, 2010, available at http://www.nytimes.com/2010/07/05 /opinion/05mon1.html.

111. Cox, supra note 6 , at 581-83.

112. Id. at 566.

113. Simon, supra note 30 , at 546 .

114. See id. at 546-47. 
Third, we ought to accept and encourage public criticism of decisions. We should encourage public interest and involvement in the judicial system, including courtroom monitoring programs. It is healthy for citizens in a democracy to be involved, and it is healthy for public officials, state or federal, to hear the views of citizens. ${ }^{115}$ Most of us are constrained by criticism and prompted to better performance by oversight. With lifetime appointments, federal judges are only modestly subject to public opinion. The criticism by the public vindicates a democratic right, lets a judge know what the public believes, and may influence a judge to make decisions that more accurately reflect the public view. Finally, federal judges should be evaluated by litigants and lawyers who appear before them, and the results should be made public. Nonpublic evaluations provide some education to federal judges, but they are easily ignored. Public evaluations serve an educational purpose and provide a minimal degree of accountability for the quality of the work done. ${ }^{116}$

Most of our states' systems provide for the selection of judges by the governor, often with the assistance of a commission responsible for reviewing and recommending candidates. ${ }^{117}$ To promote accountability, most of the states have followed the lead of California in establishing judicial commissions with some authority to censure or remove judges for violation of rules of judicial conduct but not for the merits of decisions. ${ }^{118}$ These bodies seem to function best when jointly controlled by all branches of government, with strong citizen involvement. ${ }^{119}$ State judicial terms of office are generally quite long: six years or more, with renewal by some form of election. ${ }^{120}$ Elections are favored by those who emphasize that judges should be responsible and accountable to citizens. Those who emphasize judicial independence or mistrust the election process seek to eliminate or restrict elections. Whether elections overly impinge on judicial independence or

115. Shetreet, supra note 1 , at $657-58$.

116. The system for disciplining federal judges is limited and controlled within the judicial system. Bermant \& Wheeler, supra note 88 , at 840-41.

117. See, e.g., MinN. Const. art. VI, § 8; Minn. STat. §§ 480B.01(1)-(2) (2009); McKay \& Parkison, supra note 42, at 360.

118. Cappelletti, supra note 17, at 568-69; Carrington \& Cramton, supra note 3, at 1108 ("Since 1980, 336 state court judges have been removed . . .."); see also McKay \& Parkison, supra note 42, at 368.

119. Cappelletti, supra note 17 , at 568-69.

120. See, e.g., MinN. Const. art. VI, § 7. 
adequately promote either responsibility or responsiveness is debatable, but methods exist to make elections more successful and less threatening to judicial independence. A successful judicial election is best described as one with a high level of voter participation by knowledgeable voters.

In evaluating the role of elections in judicial retention, the alternatives need to be considered. First, we have the federal pattern of lifetime appointments, which few states have chosen to follow. ${ }^{121}$ Another option is review by a commission composed of other judges, members of the legislature, executive appointees, members of the public, or a combination of all groups. Such groups can be expected to bring more information and experience to the judicial decision. However, they expose judges to the need to please the reappointing authority, and to that extent, may interfere with judicial independence. ${ }^{122}$ Such groups can be subject to bureaucratic tendencies and inbreeding so that the public interest is ignored while the interest of the participants is promoted. ${ }^{123}$ In the early years after independence, states experimented with commissions for the appointment and retention of judges. By the 1830s, states were moving away from these commissions and toward elections because of negative reactions to the degree of influence commissions were asserting and the belief that judges were making important public policy decisions that should be subject to public review. ${ }^{124}$

Today, state elections procedures are being criticized on several grounds, and some states have moved to limit judicial elections by adopting non-partisan elections, retention elections, or a format combined with commission review. ${ }^{125}$ Whatever the merits of retention elections versus lifetime appointment, the current reform efforts do not directly deal with the problems associated with elections. Our society widely subscribes to the view that democratic elections are the best means to guarantee a long-term

121. See Bermant \& Wheeler, supra note 88 , at 860 . Not surprisingly, there is no evidence that judicial independence in federal courts has been weakened by any recent criticism.

122. Russell, supra note 15 , at 16.

123. See BonNEAU \& HALL, supra note 9, at 5.

124. See id. at 138; John Schwartz, Efforts Begun to End Voting for Judges, N.Y. TiMES, Dec. 24, 2009, at A12, available at http://www.nytimes.com/2009/12/24/us /24judges.html?_r=1.

125. BonneAU \& Hall, supra note 9, at 1, 3; Canes-Wrone \& Clark, supra note 13 , at 24 . 
stable government responsible to its citizens. ${ }^{126}$ While accepting this theory, some judges and lawyers argue that judicial elections should be eliminated or restricted to preserve judicial independence. ${ }^{127}$ The case for this is not supported by databecause, again, we cannot quantify either independence or neutral decisions. The case is made on the basis of theory, and we can examine those theories to determine if they support the restrictions on elections or whether alternatives will better eliminate the basis for criticism.

First, critics of elections point out that in some states huge amounts of money are being contributed to incumbents or challengers to influence judicial decisions. This will obviously harm judicial independence. Attempts to limit contributions to candidates have been blocked by the United States Supreme Court, ${ }^{128}$ so we must limit or eliminate elections, critics argue. Rather than eliminating elections, we should focus on limiting the impact of funds. Caperton v. A.T. Massey Coal Co., Inc., starts us down this road in holding that a judge who receives a huge contribution from a party violates the due process clause by participating in a case involving that party. ${ }^{129}$ If states adopted and enforced a clear version of the ABA Model Judicial Rule, a litigant or lawyer who gave a judge more than a de minimis contribution could not have his case heard by that judge. ${ }^{130}$ A judge who accepted money from a group advocating a single position should not determine a case involving that particular position. The judge receiving the contribution would have to recuse herself. This rule preserves the democratic right to make campaign contributions but eliminates the attempt to undermine judicial independence or buy a judicial decision. We avoid the obvious conflict of interest by a judge who has received money from a litigant, and we are likely to reduce the negative impact of huge contributions in judicial elections. There is no need to eliminate elections to solve the

126. BONNEAU \& HALL, supra note 9, at 1-2, 128.

127. Id. at 1; James Walsh, First Court Shoots Down Rules on State Judges, STAR TRIB. (Minneapolis), July 30, 2010, at A1-A12 ("[T] he ruling should prompt Minnesota to drop its system of electing judges.”).

128. See Citizens United v. Fed. Election Comm'n, 130 S. Ct. 876 (2010).

129. 129 S. Ct. 2252, 2267 (2009) (discussing how a three million dollar contribution triggered due process and making it clear that states are able to enact more stringent restrictions); Wersal v. Sexton, 613 F.3d 821 (8th Cir. 2010) (invalidating restrictions on judicial fundraising and suggesting that the better answer is tighter recusal standards).

130. Model Code of Judicial Conduct 2.11A(4) (2010). 
problem of campaign contributions impinging on judicial independence.

Second, critics complain that elections cause judges to announce their decisions, precluding them from making independent decisions when the issue actually arises before them. ${ }^{131}$ There are two reasons why this argument is incorrect. First, it assumes that most judges have not committed to a position on the serious current issues. In fact, most incumbent judges, on issues within their typical jurisdiction, will have committed to a position by prior decisions. On the issues of interest to typical voters, nearly all thoughtful lawyers, the type we would like to see as judges, have formed opinions on these subjects well before an election. ${ }^{132}$ These opinions will determine, or at the least, influence their decisions if they are elected, regardless of whether they announce their view in the election. Second, it is better that a judge announce a view actually held so that voters can base their vote on an evaluation of a policy position which will impact future judicial decisions. It is better for the litigant to know the judge's view than to be blindsided by a secretly held position. Judges who have previously decided an issue do not recuse themselves on the next similar case. Judges who have a fixed, but unannounced, view of a matter do not recuse themselves if a similar matter is presented by a new case. "A judge's lack of predisposition regarding the relevant legal issues in a case has never been thought a necessary component of equal justice...." ${ }^{133}$ The fact that the judge has candidly disclosed a general position on issues in an election should not greatly impact independence because it is simply disclosure of the judge's longdeveloped opinion. Disclosure should enhance the election or selection process. ${ }^{134}$

While Republican Party $v$. White only permitted judicial candidates to state their views, the logic of the decision applies equally to candidates for judicial appointments. The fact that a state, or the federal government for that matter, has an election or

131. Republican Party of Minn. v. White, 536 U.S. 765 (2002) (in a 5-4 opinion discussing a judge's ability to discuss politics, the Court held Minnesota's requirement which disallowed discussion of political issues to be unconstitutional).

132. Id. at 776-77.

133. Id. at 777 .

134. The White rationale, to the extent it is based on whether a state has judicial elections, is not particularly convincing. The right of freedom of speech does not depend on whether there is an election. 
appointment system does not change the First Amendment right of the candidate to speak. The policy reasons supporting judicial accountability apply to appointed as well as elected judges. The minimal intrusion on judicial independence from a candidate disclosing a previously held position does not support a candidate's refusal to disclose these views. It is reasonable to expect candidates seeking any judicial position to disclose their views on the major judicial issues of the day.

Critics of elections claim that voters are ignorant of the qualifications of judicial candidates and will not make informed choices in the election. ${ }^{135}$ Unless we are to eliminate elections altogether, the reasonable approach to this problem is to provide the public with pertinent information. There are two categories of information that would be helpful. First, for incumbents, there is much performance information that should be available, including workload data, appeals results, removal frequency, and evaluation results. Making this data public before an election will give potential candidates an opportunity to determine whether an incumbent judge is susceptible to challenge on the basis of performance. It will give the public pertinent information to determine whether an incumbent merits reelection. Second, the public should have information on the judicial candidates' views on major social or political issues that are likely to come before the court. That is not to say a candidate should discuss his decision in a future case, because that discussion should await the full development of facts in the case. But, for example, in a race for a seat on a court that has general criminal jurisdiction, the public should be able to tell whether the candidates believe the current rate of incarceration is too high or too low. The judicial election process can be much improved. Providing the public with substantial information about performance and positions will allow citizens a meaningful basis on which to cast a vote.

Finally, critics of elections complain that judicial races lack visibility so that voters do not learn enough about candidates to make informed choices. ${ }^{136}$ However, when judicial races do become highly visible, these same critics complain that the increased profile results in politics and money damaging the judicial system. The negative impact of money can be largely

135. See BonNeAU \& HALl, supra note 9, at 1-2.

136. Id. at 3 . 
limited by requiring judges to recuse themselves from disputes involving contributors. The solution to low visibility is not to further decrease visibility, but to provide sufficient information so that the issues become visible. The movement from partisan to non-partisan to retention elections tends to reduce participation by voters rather than focus attention on the races. ${ }^{137}$ The absence of meaningful information about incumbent judges and challengers leads to lack of interest. In our present elections, even the most diligent voter will have difficulty finding a reasonable basis on which to differentiate candidates. The expectation that voters have a reasonable basis for a decision requires that the judicial system make available the information needed to make those reasonable decisions.

\section{CONCLUSIONS}

The essential elements of our federal and state systems for selecting and retaining judges are unlikely to change soon. The federal system of presidential appointments with life tenure provides strong support for judicial independence but provides relatively little support for public accountability or responsiveness. The state systems with appointed judges subject to some form of retention election are criticized where the election process is imperfect and some of the ancillary aspects of elections interfere with judicial independence. Both systems, lifetime appointment and elections, have flaws. While the ultimate goals of democratic accountability and judicial independence are ideals that will never be perfectly achieved, we can, within the structures of our present systems, improve our quest to reach these conflicting goals.

Most important is that the ethos of neutral application of the law be preserved. Appointing and confirming authorities should continue to state this as a primary requirement of appointment. Rules of judicial conduct should continue to emphasize this goal. We should move beyond this general rhetoric, however. In the federal system, the requirements should be clear that a judge with any financial interest in a matter, other than one in common with all citizens, should not be the judge of the matter. The same rule should apply to state judges with the specific additional requirement that a judge receiving more than a de minimis campaign contribution from a party, lawyer, or single interest

137. Id. at 138. 
group should not judge a matter involving the contributor. If we truly prize the goal of judicial independence, we will enact and enforce specific provisions to limit the impact of financial interests on judicial decisions.

In the federal system that emphasizes independence over accountability, we should take modest steps to promote accountability. First, we should encourage vigorous public discussion, including criticism, of judicial decisions. Criticism should not be stifled by claims that it interferes with judicial independence. The democratic goals of public debate and accountability surely trump any incidental impact on judicial independence. Second, the judicial system ought to make available full performance data, including evaluation data, so there is a measure of accountability even for a judge with life tenure. Finally, candidates for judicial positions should disclose their views on important judicial issues so that appointing authorities can make more informed decisions.

In our state systems, the presence of some form of election makes it even more important that information on judicial performance be made available so that the voters have a basis to cast informed votes. State-sponsored judicial monitoring groups appear to perform a valuable function. Generally, their review of complaints involving judges' compliance with rules of judicial conduct enforces accountability without infringing judicial independence. Encouraging candidates to disclose their views on subjects where they obviously have a view will avoid the disingenuous claim that judges do not have views on the more serious issues of the day. Eliminating the impact of financial interest and campaign contributions on individual cases will remove an obvious impropriety and enhance the public perception that judges will be fair and impartial.

The subject of judicial independence and accountability is extremely important in a democratic society. It is a complex subject but one which cries out for better understanding. While the judiciary has much to say about this subject, it should not have the final say. Judges have self-interest in the outcome. Many judges may prefer lifetime appointments to elections, oppose public evaluation, or resist making performance data available. Elections, evaluations, and court monitoring may make some judges uncomfortable, and we may hear a claim of interference with judicial independence. But whether or not these proposals 
are appropriate should be settled by the public through elected representatives who can determine the appropriate provisions to balance and enhance the goals of judicial independence and democratic accountability. 